\title{
The RELATIONSHIP BETWEEN RENEWABLE ENERGY CONSUMPTION AND ECONOMIC GROWTH IN NON-OECD COUNTRIES
}

\author{
Tuncer GÖODEL $\dot{I}^{1}$

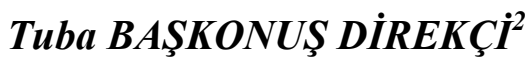

\begin{abstract}
With its increasing share in total energy consumption in recent years, renewable energy has caused countries to shift their policies towards this direction. The search for alternatives to nonrenewable energy sources, which are expected to come close to running out between the years of 2050 and 2060, has been increasing each passing day. Alternative energy sources are highly important for our future, especially in this day and age in which energy wars are leading to serious destructions. Countries will be able to produce both cleaner and more economical energy by means of renewable energy sources. In the present study, the relationship between renewable energy consumption and economic growth in 49 non-OECD countries was analyzed for the period between 1980 and 2012. For this purpose, firstly, the cross-section dependence among the countries was tested. Due to the presence of cross-section dependence among the countries, a second generation unit root test (Pesaran CADF(2007)) and cointegration test (Westerlund Durbin-H (2008)) were used. The result of the analyses revealed the existence of a long term relationship between renewable energy consumption and economic growth. At the last stage of the study, the long term cointegration coefficients were estimated using the Common Correlated Effects (CCE). The findings obtained in the study are compatible with our expectations and the literature, and an increase in renewable energy consumption has a positive effect on growth and development.
\end{abstract}

Keywords: Panel Data Analysis, Economic Growth, Renewable Energy.

Jel Codes: C33, O4, Q43.

\section{Yenilenebílír ENERJi TüKETIMİ İLE EKONOMIK BÜYÜME ARASINDAKİ İLIŞKI: OECD DIȘI ÜLKELER}

Özet

Son yıllarda toplam enerji tüketimindeki payı artan yenilenebilir enerji, ülkelerin politikalarını bu yöne kaydırmasına sebep olmuştur. 2050 ile 2060 yılları arasında tükenmeye yaklaşması beklenen yenilenemeyen enerji kaynaklarına alternatif arayışları her geçen gün artmaktadır. Özellikle enerji savaşlarının ciddi yıkımlara yol açtı̆̆ı günümüzde alternatif enerji kaynakları, geleceğimiz için son derece önem arz etmektedir. Ülkeler, yenilenebilir enerji kaynakları ile hem temiz hem daha ekonomik enerji üretebileceklerdir. Bu çalışmada, OECD dışı 49 ülkenin yenilenebilir enerji tüketimi ile ekonomik büyüme arasındaki ilişki 1980 ile 2012 dönemi için analiz edilmiştir. Bu amaçla, ilk önce ülkeler arasında yatay kesit bağımlılığı test edilmiştir. Ülkeler arasında yatay kesit bağımlılığı olmasından doyalı ikinci nesil birim kök testi (Pesaran CADF(2007)) ve eşbütünleşme testi (Westerlund Durbin-H (2008)) kullanılmıştır. Yapılan analizler sonucu, yenilenebilir enerji tüketimi ile ekonomik büyüme arasında uzun dönemli ilişki olduğu ortaya çıkmıştır. Çalışmanın son aşamasında ise uzun dönem eşbütünleşme katsayılarının tahmini Common Correlated Effect (CCE) yardımıyla tespit edilmiştir. Elde edilen bulgular, beklentilerimiz ve literatür ile uyumlu olup, yenilenebilir enerji tüketimindeki artış büyüme ve kalkınmayı olumlu etkilemektedir.

Anahtar Kelimeler: Panel Veri Analizi, Ekonomik Büyüme, Yenilenilir Enerji.

Jel Kodları: C33, O4, Q43.

\footnotetext{
${ }^{1}$ Arş. Gör. Gaziantep Üniversitesi, İktisat Bölümü, Şehitkamil/Gaziantep (tgovdeli@gmail.com)

${ }^{2}$ Doç. Dr. Gaziantep Üniversitesi, İktisat Bölümü, Şehitkamil/Gaziantep (baskonus@gmail.com)
} 


\section{INTRODUCTION}

Energy use dates back to thebeginning of human civilization in prehistoric ages. With the discovery of fire, prehistoric people started to use energy sources for heating and cooking. Human civilization evolved with the use of the locomotive, the nuclear energy, the automobile, the airplane, and the personal computer. Thus, energy use has continued to increase throughout the centuries. In the period after 1950, countries fought for the control and the security of energy sources (Michaelides, 2012:1).

Types of energy are divided into two categories as renewable and nonrenewable energy. Nonrenewable energy sources are those that run out when they are used and cannot be replaced. Fossil sources and uranium, which is the material of nuclear energy, can be given as examples to nonrenewable sources. Renewable energy sources, on the other hand, are those that can be recovered at the moment they are used at a rate that is equal to or less than the rate at which the same source is replenished. Solar energy and wind energy can be given as examples to renewable energy sources (Fanchi and Fanchi, 2005:1-2).

The continuously increasing demand for energy in the world results in the rapid decrease of nonrenewable energy sources. For this reason, the importance of alternative energy sources increases each passing day. Early models such as Solow (1956) cannot explain the development of technology.Thus, this model regards technology as exogenous, and cannot put forth energy and the sources. However, some economists state that energy plays a significant role in economic growth, and in addition, the importance of energy increased after the industrial revolution (Wrigley, 1990; Allen, 2009). Some other economists, such as Hall et al., (2003), regardenergy consumption as a potential source for economic growth (Omri and Chaibi, 2014).

Oil and natural gas are not solutions that can be adequate for the energy needs of the world in the long run. Coal and nuclear energy cause serious environmental pollution. Coal requires mining operations and the combustion of coal results in intensive environmental pollution due to the emission of carbon dioxide and sulfur dioxide. The serious problem of nuclear energy is the storage and disposal of wastes. For these reasons, alternative energy sources (wind energy, solar energy, etc.) are expected to take the place of the primary energy sources in the next a few decades (Johnson, 2006).

\section{LITERATURE REVIEW}

The fact that renewable energy sources pollute the environment less compared to nonrenewable energy sources and their renewable nature increases the importance of such sources. The number of studies in the literature investigating the relationship between renewable energy consumption and economic growth has been increasing in recent years.

In the first empirical study investigating the relationship between energy consumption and economic growth, Kraft and Kraft (1978) used the energy consumption and GDP data for the period between 1947 and 1974. In their results, they detected a unidirectional causality relationship from GDP to energy consumption.

Apergis and Payne (2010) analyzed the relationship between renewable energy consumption and economic growth in 20 OECD countries for the period between 1985 and 2005. In the results obtained by using Panel Cointegration Test (Pedroni), Panel FMOLS, and Panel Granger Causality Test, a long term relationship was observed between the series and it was found that a $1 \%$ increase in renewable energy consumption increased economic growth by $0.76 \%$. The causality analysis indicated a bidirectional relationship between renewable energy consumption and economic growth. In another study on OECD countries, Salim et al. (2014) examined 29 countries for the period between 1980 and 2012. In the study conducted by using Panel Cointegration Test (Westerlund 2006, 2007), Panel Cointegration Test (CCE), and Panel Granger Causality Test, cointegration relationship was found,and a $1 \%$ increase in renewable energy consumption increased economic growth at a rate of $0.101 \%$. The results of the causality analysis indicated a unidirectional causality between renewable energy consumption and GDP. Inglesi-Lotz (2016) analyzed 34 OECD countries for the period between 1990 and 2010. According to the results of the Least Squares with Fixed Effects and Panel Cointegration Test (Pedroni), there was a cointegration relationship among the series, and a $1 \%$ increase in renewable energy consumption caused a $0.105 \%$ increase in economic growth.

In a study on EU countries for the period between 1997 and 2007, Menegaki (2011) used the data for real GDP per capita, energy consumption, $\mathrm{CO}_{2}$ emission, and the share of renewable energy in consumption. The results of the unidirectional random effect model and Panel Causality Test did not reveal a causality relationship 
between renewable energy consumption and economic growth. In another study on EU countries, Uçan et al., (2014) examined the EU countries for the period between 1990 and 2011.In their analyses, they conducted Panel Cointegration Test (Pedroni), Panel FMOLS and VECM Granger Causality Test by using Real GDP, Renewable Energy Consumption, Nonrenewable Energy Consumption, $\mathrm{CO}_{2}$ Emission, Real Gross Fixed Capital Formation, and Energy Technology Research and Development Indicators series. In their findings, they detected the presence of a cointegration relationship and a causality from renewable energy consumption to economic growth. Tiwari (2011) analyzed 16 EU countries for the period between 1965 and 2009. In the study conducted by using GDP, Renewable Energy Consumption, Nonrenewable Energy Consumption, and $\mathrm{CO}_{2}$ Emission data, Panel VAR and Panel Granger Causality Tests were employed and a bidirectional causality relationship was detected between renewable energy consumption and economic growth. Alper and Alper (2017) have examined the relationship between $\mathrm{CO} 2$, energy consumption and economic growth in Turkey. According to the findings obtained, elasticity coefficient of 0.11 for energy consumption, elasticity coefficient of growth i.in 0.8 was estimated.

Apergis and Payne (2012) conducted Panel Cointegration and Panel Granger Causality Tests in their study conducted by using the data from 6 Central American countries for the period between 1990 and 2007.Their findings revealed the presence of cointegration and also a bidirectional relationship between renewable energy and economic growth.

Sebri and Ben-Salha (2014) analyzed the BRICS countries for the period between 1971 and 2010. They used Real GDP, Renewable Energy Consumption, $\mathrm{CO}_{2}$ Emission, and trade openness data in their analyses. The results obtained using ARDL, Panel FMOLS, Panel DMOLS and VECM Granger Causality Tests revealed the existence of cointegration in the series, and a bidirectional causality between renewable energy consumption and economic growth.

\section{METHODOLOGY}

\section{II.I. Cross-Section Dependence Tests}

In the present study, firstly, cross-section dependence was tested to determine the panel unit root tests to be used. If there is no cross-section dependence present in the panel data, first generation panel unit root tests can be used. However, if cross-section dependence is present in the panel data, the use of second generation panel unit root tests enables the performance of a more effective and stronger estimation.

The methods used for testing cross-section dependence in panel data sets are Breusch-Pagan (1980) $\mathrm{CDLM}_{1}$ test, Pesaran et al. (2004) $\mathrm{CDLM}_{2}$ test,andPesaranet al. (2008) Bias Adjusted CD test.

$\mathrm{H}_{0}$ : There is no cross-section dependence.

$\mathrm{H}_{1}$ : There is cross-section dependence.

If the probability values are found to be smaller than 0.05 in the results obtained from Breusch-Pagan (1980) $\mathrm{LM}_{1}$ test, Pesaran et al. (2004) $\mathrm{CD}_{\mathrm{LM}_{2}}$ test, and Pesaran et al. (2008) Bias Adjusted CD test, $\mathrm{H}_{0}$ is rejected at $5 \%$ level of significance and it is concluded that there is cross-section dependence among the units forming the panel.

$$
\mathrm{LM}_{1}=\mathrm{T} \sum_{\mathrm{i}=1}^{\mathrm{N}-1} \sum_{j=i+1}^{\mathrm{N}} \hat{\rho}_{\mathrm{ij}}^{2}
$$

$\hat{\rho}_{\mathrm{ij}}$ : shows the estimates of the cross-sectional correlations among residuals.

$$
\hat{\rho}_{\mathrm{ij}}=\hat{\rho}_{\mathrm{ji}}=\frac{\sum_{\mathrm{t}=1}^{\mathrm{T}} \hat{v}_{\mathrm{it}} \hat{v}_{\mathrm{jt}}}{\left(\sum_{\mathrm{t}=1}^{\mathrm{T}} \hat{v}_{\mathrm{it}}\right)^{1 / 2}\left(\sum_{\mathrm{t}=1}^{\mathrm{T}} \hat{v}_{\mathrm{jt}}\right)^{1 / 2}}
$$

Under $\mathrm{H}_{0}$ hypothesis, there is no cross-section dependence. Under $\mathrm{H}_{0}$ hypothesis, $\mathrm{N}$ is stationary and $\mathrm{T} \rightarrow \infty$. The test statistics has a Chi-square asymptotic distribution with $\mathrm{N}(\mathrm{N}-1) / 2$ degrees of freedom. $\mathrm{LM}_{1}$ test is used when the time dimension is larger than the cross-section dimension (i.e., $\mathrm{T}>\mathrm{N}$ ). 


$$
\mathrm{CD}_{\mathrm{LM} 2}=\left(\frac{1}{\mathrm{~N}(\mathrm{~N}-1)}\right)^{1 / 2} \sum_{\mathrm{i}=1}^{\mathrm{N}-1} \sum_{j=i+1}^{\mathrm{N}}\left(\mathrm{T} \hat{\rho}_{\mathrm{ij}}^{2}-1\right)
$$

$\mathrm{CD}_{\mathrm{LM}_{2}}$ Pesaran (2004) test statistics shows standard normal distribution under $\mathrm{H}_{0}$ hypothesis in case of $\mathrm{T} \rightarrow \infty$ and $\mathrm{N} \rightarrow \infty . \mathrm{CD}_{\mathrm{LM}_{2}}$ test is used when the time dimension is larger than the cross-section dimension (i.e., $\mathrm{T}>\mathrm{N})$.

Bias adjusted CD test $=\left(\frac{2}{\mathrm{~N}(\mathrm{~N}-1)}\right)^{1 / 2} \sum_{\mathrm{i}=1}^{\mathrm{N}-1} \sum_{j=i+1}^{\mathrm{N}} \hat{\rho}_{\mathrm{ij}}^{2} \frac{(\tau-K-1) \hat{\rho}_{i j}-\hat{\mu}_{T i j}}{v_{T i j}} \sim N(0,1)$

In Equation (4), $\hat{\mu}_{T i j}$ is the mean, $v_{T i j}$ is the variance, and the test statistics to be obtained would show asymptotic standard normal distribution. Bias adjusted CD test is used when the cross-section dimension is larger than the time dimension (i.e., N>T). (Pesaran et al., 2008).

Table 1: Cross-section Dependence Test Results

\begin{tabular}{|c|c|c|c|}
\hline $\begin{array}{l}\text { Regression Model: } L G D P_{t}=\alpha_{0}+\alpha_{1} L Y E T_{t}+\varepsilon_{t} \\
\text { TESTS }\end{array}$ & LGDP & LYET & PANEL \\
\hline CDLM $_{1}$ (Breusch and Pagan, 1980) & $\begin{array}{l}1.397,377 \\
{[0,000]}\end{array}$ & $\begin{array}{l}1.541,370 \\
{[0,000]}\end{array}$ & $\begin{array}{l}7.044,136 \\
{[0,000]}\end{array}$ \\
\hline $\mathrm{CDLM}_{2}$ (Pesaran, 2004 CDLM) & $\begin{array}{l}4,565 \\
{[0,000]}\end{array}$ & $\begin{array}{l}7,534 \\
{[0,000]}\end{array}$ & $\begin{array}{l}120,999 \\
{[0,000]}\end{array}$ \\
\hline Bias-adjusted CD test (Pesaran et al., 2008) & $\begin{array}{l}-6,153 \\
{[0,000]}\end{array}$ & $\begin{array}{l}-1,651 \\
{[0,049]}\end{array}$ & $\begin{array}{l}281,032 \\
{[0,000]}\end{array}$ \\
\hline
\end{tabular}

The results of the cross-section dependence tests are presented in Table 1. Since the findings revealed that the p-statistics was smaller than $0.05, \mathrm{H}_{0}$ hypothesis was rejected and the $\mathrm{H}_{1}$ hypothesis stating that there is cross-section dependence was accepted. According to the results, there is cross-section dependence among the countries constituting the panel.

Since there is cross-section dependence, the panel unit root tests and panel cointegration tests to be used need to be second generation panel unit root and panel cointegration tests that take cross-section dependence into account.

CADF and CIPS tests, which are second generation panel unit root tests, and Westerlund Durbin Hausman (2008) Panel Cointegration Test were used in the study.

\section{II.II. Panel Unit Root Test}

Heterogeneous panel unit root test (IPS) developed by Im et al., (2003) can be used for investigating the stationarity of the time series. This test is based on the augmented Dickey-Fuller (ADF) regression.

$$
\Delta x_{i t}=z_{i t}^{\prime} \gamma+\rho_{i} x_{i t-1}+\sum_{j=1}^{k_{i}} \phi_{i j} \Delta x_{i t-j}+\varepsilon_{i t}
$$

where $k_{i}$ refers to the lag length, $z_{i t}$ is a vector of deterministic terms and $\rho_{i}$ is the cross-section specific first degree autoregressive parameters.

Standard IPS test may lead to spurious inferences in case of spillovers or common shocks. For this reason, it is suggested that the cross-sectionally augmented IPS test proposed by Pesaran (2007) be employed. This test is formed through augmenting the ADF regression with the cross-sectional averages of lagged levels and first differences of the individual series (Herzer, 2016). Therefore, the cross-sectionally augmented ADF (CADF) regression is given by;

$$
\Delta x_{i t}=z_{i t}^{\prime} \gamma+\rho_{i} x_{i t-1}+\sum_{j=1}^{k_{i}} \phi_{i j} \Delta x_{i t-j}+\alpha_{i} \bar{x}_{t-1}+\sum_{j=0}^{k_{i}} \eta_{i j} \Delta \bar{x}_{t-j}+v_{i t}
$$


where $\bar{x}_{t}$ refers to the cross-section mean of $x_{i t}$ and $\bar{x}_{t}=N^{-1} \sum_{i=1}^{n} x_{i t}$. The presence of a unit root in the panel is accepted by taking the simple average of the individual CADF statistics calculated for each crosssection.

CIPS $=t-$ bar $=N^{-1} \sum_{i=1}^{N_{i}} t_{i}$.

where $t_{i}$ is the OLS t-ratio of $\rho_{i}$ in Equation $Z$. The obtained results are tabulated by using the critical table values in Pesaran (2007).

Table 2: CADF and CIPS Unit Root Test Results

\begin{tabular}{ccccc|cccc}
\hline & \multicolumn{4}{c|}{ WITH CONSTANT } & \multicolumn{4}{c}{ WITH CONSTANT and TREND } \\
\hline & Ingdp & Inyet & $\Delta$ Ingdp & $\Delta$ Inyet & Ingdp & Inyet & $\Delta$ Ingdp & $\Delta$ Inyet \\
& cadfstatist & cadfstatist & cadfstatistic & cadfstatistic & cadfstatistic & cadfstatistic & cadfstatistic & cadfstatistic \\
& ics & ics & $\mathbf{s}$ & $\mathbf{s}$ & $\mathbf{s}$ & $\mathbf{s}$ & $\mathbf{s}$ & $\mathbf{s}$ \\
\multirow{2}{*}{ CIPS } & -1.933 & -2.100 & -3.284 & -3.838 & -2.407 & -2.391 & -3.412 & -4.059 \\
\hline
\end{tabular}

Note: Critical table values of CIPSfor $\mathrm{N}=49$ and $\mathrm{T}=33$ with constant are given as 2.23 at $1 \%$ and 2.11 at $5 \%$ in Table IIb on p. 280 , and with constant and trend as -2.73 at $1 \%$ and -2.61 at $5 \%$ in Table IIc on p.281. Maximum lag length was taken as 3 , and optimum lag lengths were determined based on Schwarz Information Criterion. $* * *$ and $* *$ refer to significance levels at $1 \%$ and $5 \%$, respectively.

In Table 2, the results with constant revealed that economic growth and renewable energy consumption data were not stationary at level. The findings obtained after taking the differences of the series showed that the series were stationary at the level of I(1). The results with constant and trend showed that the series had a unit root at the level, but they did not have a unit root after the differences were taken. Thus, it was concluded that both series were stationary at the level of I(1).

\section{II.III. Test Results for the Homogeneity of Cointegration Coefficients}

It is highly important to test the homogeneity of cointegration coefficients. The cointegration test to be used in case of homogeneity or heterogeneity would also change. The homogeneity test results for non-OECD countries are given below.

Table 3: Homogeneity test results for non-OECD Countries

\begin{tabular}{lll}
\hline & Test Statistics & Probability value \\
\hline$\widetilde{\boldsymbol{\Delta}}$ & 53,366 & 0,000 \\
$\widetilde{\boldsymbol{\Delta}}_{\text {adj }}$ & 55,889 & 0,000 \\
\hline
\end{tabular}

According to the results of the homogeneity test, the variables constituting the panel data set wereheterogeneous. The estimated probability value was significant at a level of $5 \%$ and the alternative hypothesis was accepted. Since the series were stationary at the level of I(1), Westerlund Durbin Hausman (2008) Panel Cointegration Test (Durbin-H) was implemented.

\section{II.IV. Durbin-H Cointegration Test}

Durbin-H cointegration test makes it possible to conduct panel cointegration analysis in case the independent variables are $\mathrm{I}(1)$ or $\mathrm{I}(0)$ on condition that the dependent variable is $\mathrm{I}(1)$, and takes the common factors into account (Westerlund, 2008).

In Durbin-H Cointegration Test method, Westerlund (2008) examines the presence of a cointegration relationship by means of two different tests. The first of these tests is Durbin-H panel test, and the second is Durbin-H group test. In Durbin-H group test, Westerlund (2008) allows the autoregressive parameter to differ between cross-sections. In this test, $\mathrm{H}_{0}$ hypothesis states that there is no cointegration, and $\mathrm{H}_{1}$ hypothesis indicates that there is cointegration relationship for at least some cross-sections. Westerlund (2008) Durbin- $\mathrm{H}$ 
panel test considers that the autoregressive parameter is the same for all cross-sections. While $\mathrm{H}_{0}$ hypothesis indicates that there is no cointegration, $\mathrm{H}_{1}$ hypothesis indicates that there is panel cointegration.

Panel data model is stated as follows:

$$
\begin{aligned}
& y_{i t}=\alpha_{i}+\beta_{i} x_{i t}+z_{i t} \\
& x_{i t}=\delta x_{i t-1}+w_{i t}
\end{aligned}
$$

It is assumed that the disturbance $z_{i t}$ obeys the following set of equations that allow for cross-section dependence through the use of common factors.

$$
\begin{aligned}
& z_{i t}=\lambda_{i}^{\prime} F_{t}+e_{i t} \\
& F_{j t}=p_{j} F_{j t-1}+u_{j t} \\
& \boldsymbol{e}_{i t}=\phi_{i} \boldsymbol{e}_{i t-1}+v_{i t}
\end{aligned}
$$

For each $\mathrm{j}, p_{j}<1$.

where $F_{t}$ refers to a k-dimensional vector of common factors $F_{j t}(\mathrm{j}=1 \ldots \mathrm{k}) . \lambda_{i}$ is a conformable vector of factor loadings.

To construct the Durbin-H test, we take the first difference of Equation 10.

$\Delta z_{i t}=\lambda_{i}^{\prime} \Delta F_{t}+\Delta e_{i t}$

If $\Delta z_{i t}$ was known, then $\lambda_{i}$ and $\Delta F_{t}$ could be estimated. However, $\Delta z_{i t}$ is not known. For this reason, it is necessary to apply principal components to its OLS estimate instead, which can be written as follows:

$$
\Delta \hat{z}_{i t}=\Delta y_{i t}-\hat{\beta}_{i} \Delta x_{i t}
$$

The principal components estimator $\Delta F_{t}$ of $F_{t}$ is obtained by computing $\sqrt{T-1}$ times the eigenvectors corresponding to the $\mathrm{K}$ largest eigenvalues of the (T-1)x(T-1) matrix $\Delta \hat{z} \Delta \hat{z}^{\prime}$. Here, $\hat{\lambda}$ is calculated with $\hat{\lambda}=\frac{\Delta \hat{F}^{\prime} \Delta z}{\mathrm{~T}-1}$.

The first difference of the residuals can be stated as follows:

After calculating $\widehat{\triangle F}$ and $\hat{\lambda}_{i}$, the difference of the residuals is calculated as:

$$
\begin{aligned}
& \Delta \hat{\boldsymbol{e}}_{i t}=\Delta \hat{z}_{i t}-\lambda_{i}^{\prime} \Delta \hat{F}_{t} \\
& \hat{\boldsymbol{e}}_{i t}=\sum_{j=2}^{t} \Delta \hat{\boldsymbol{e}}_{i j}
\end{aligned}
$$
$\phi_{i}=1$.

Testing the $\mathrm{H}_{0}$ stating that there is no cointegration is asymptotically equivalent to testing whether

$$
\hat{e}_{i t}=\phi_{i} \hat{e}_{i t-1}+\text { error }
$$

Another estimator required for constructing the Durbin-H test is the kernel estimator. The kernel estimator can be defined as follows:

$$
\widehat{\omega}_{i}^{2}=\frac{1}{T-1} \sum_{j=M_{i}}^{M_{i}}\left(1-\frac{j}{M_{i}+1}\right) \sum_{t=j+1}^{T} \hat{\mu}_{i t} \hat{\mu}_{i t-1}
$$

where $\hat{\mu}_{i t}$ is the OLS residuals obtained from Equation (9). $M_{i}$ is a bandwidth parameter. The value of $\hat{\omega}_{i}^{2}$ is a consistent estimate of $\hat{\omega}_{i}^{2}$, the long-run variance of $\hat{\mu}_{i t}$. The corresponding contemporaneous variance estimate can be denoted by $\hat{\sigma}_{i}^{2}$. After these estimates are performed, the two variance ratios can be calculated:

$$
\hat{S}_{i}=\frac{w_{i}^{2}}{\sigma_{i}^{4}} \mathrm{ve} \hat{S}_{n}=\frac{w_{n}^{2}}{\left(\sigma_{n}^{2}\right)^{2}}
$$

where; 


$$
\widehat{\omega}_{i}^{2}=\frac{1}{n} \sum_{i=1}^{n} \widehat{\omega}_{i}^{2} \mathrm{ve} \hat{\sigma}_{i}^{2}=\frac{1}{n} \sum_{i=1}^{n} \hat{\sigma}_{i}^{2} \text { dir. }
$$

After these calculations are performed, the Durbin-H test statistics can now be obtained through:

$$
\begin{aligned}
& D H_{G}=\sum_{i=1}^{n} \hat{S}_{i}\left(\tilde{\phi}_{i}-\hat{\phi}_{i}\right)^{2} \sum_{t=2}^{T} e_{i t-1}^{2} ; \\
& D H_{p}=\hat{S}_{n}\left(\tilde{\phi}_{i}-\hat{\phi}_{i}\right)^{2} \sum_{i=1}^{n} \sum_{t=2}^{T} e_{i t-1}^{2} .
\end{aligned}
$$

The results of the Durbin-H Panel Cointegration Test, which takes cross-section dependence and the heterogeneity of cross-section slope parameters into consideration, are presented below.

Table 4: Durbin-H Cointegration Test Results for Non-OECD Countries

\begin{tabular}{ll}
\hline TESTS & PANEL \\
\hline Durbin-H Group Statistics & 2,338 \\
& {$[0,009]$} \\
Durbin-H Panel Statistics & 3,448 \\
& {$[0,000]$} \\
\hline
\end{tabular}

Note: The values in the table indicate CD-test statistics, and the values in square brackets indicate probability values.

In Durbin-H Cointegration method, the null hypothesis is constructed as there is no cointegration among the variables. In the findings obtained, the null hypothesis was rejected in Durbin-H Group Statistics and Durbin$\mathrm{H}$ Panel Statistics. For this reason, the presence of cointegration among the variables was detected. After detecting the cointegration among the variables, the estimation of long-term cointegration coefficients was performed.

\section{II.V. Estimation of Long-Term Cointegration Coefficients}

Since a cointegration relationship was detected in non-OECD countries, it was necessary to find the longterm cointegration coefficients of the countries. The results obtained by using the CCE estimator are presented below.

Table 5: Long-term cointegration coefficients for non-OECD countries

\begin{tabular}{lll}
\hline COUNTRIES & COINTEGRATION COEFFICIENTS & t value \\
\hline Albania & 0,050 & 0,365 \\
\hline Algeria & $0,037 * * *$ & 3,364 \\
\hline Argentina & $-0,007$ & $-0,047$ \\
\hline Bangladesh & $-0,019$ & $-0,731$ \\
Belize & $-0,209 * *$ & $-2,488$ \\
\hline Bhutan & $0,048^{* * *}$ & 4,800 \\
Bolivia & $-0,003$ & $-0,028$ \\
\hline Brazil & 0,075 & 0,630 \\
Bulgaria & $0,127 * *$ & 1,984 \\
\hline Burundi & 0,025 & 0,962 \\
Central African Republic & $0,172 *$ & 1,293 \\
China & 0,085 & 0,337 \\
Comoros & $0,053 * *$ & 1,893 \\
\hline Democratic Republic of the Congo & $1,231 * * *$ & 4,681 \\
\hline Dominica & 0,032 & 0,780 \\
\hline El Salvador & $-0,259 * * *$ & $-2,333$ \\
\hline Equatorial Guinea & 0,501 & 0,871 \\
\hline
\end{tabular}


Tuncer Gövdeli \& Tuba Başkonuş Direkçi

\begin{tabular}{|c|c|c|}
\hline India & $0,230 * * *$ & 3,108 \\
\hline Iran & $0,065 * * *$ & 3,421 \\
\hline Iraq & $-0,009$ & $-0,155$ \\
\hline Kenya & $0,088 * *$ & 2,200 \\
\hline Malawi & 0,160 & 1,185 \\
\hline Mali & $-0,100 * * *$ & $-2,941$ \\
\hline Mauritania & 0,004 & 0,190 \\
\hline Mauritius & 0,015 & 0,268 \\
\hline Mozambique & $0,043 * * *$ & 4,778 \\
\hline Nicaragua & $-0,022$ & $-0,500$ \\
\hline Nigeria & $-0,229 * *$ & $-1,537$ \\
\hline Pakistan & $0,315^{* *}$ & 2,299 \\
\hline Panama & $-0,004$ & $-0,053$ \\
\hline Papua New Guinea & $-0,001$ & $-0,007$ \\
\hline Paraguay & $0,073 * * *$ & 3,650 \\
\hline Peru & $-0,105$ & $-0,319$ \\
\hline Romania & $-0,402 * *$ & $-2,138$ \\
\hline Ruanda & 0,029 & 0,246 \\
\hline South Africa & $0,012 *$ & 1,500 \\
\hline Sri Lanka & $0,109 * * *$ & 2,422 \\
\hline Sudan & $-0,114 * * *$ & $-2,850$ \\
\hline Surinam & 0,033 & 0,717 \\
\hline Swaziland & $0,141^{*}$ & 1,424 \\
\hline The Dominican Republic & $-0,023$ & $-0,590$ \\
\hline The Philippines & $-0,134 * * *$ & $-5,154$ \\
\hline Togo & $-0,003$ & $-0,067$ \\
\hline Trinidad and Tobago & $-0,071$ & $-0,922$ \\
\hline Tunisia & $-0,006$ & $-0,300$ \\
\hline Uruguay & $-0,056$ & $-0,918$ \\
\hline Venezuela & $0,160 * *$ & 2,051 \\
\hline Zambia & $0,695 * * *$ & 4,860 \\
\hline Zimbabwe & $-0,378 * * *$ & $-3,345$ \\
\hline PANEL & $0,050^{*}$ & 1,406 \\
\hline
\end{tabular}

Note: Autocorrelation and heteroskedasticity problems in the estimations were corrected using the Newey-West method. ***, $* *$ and * refer to stationarity at significance levels of $1 \%, 5 \%$ and $10 \%$, respectively.t value is significant at a level of $1 \%$ if greater than 2.32 , at a level of $5 \%$ if greater than 1.65 , and at a level of $10 \%$ if greater than 1.28 .

The individual cointegration parameters of the 49 non-OECD countries are given in Table 5. According to the results, an inverse relationship was found between economic growth and renewable energy consumption in Belize, El Salvador, Philippines, Mali, Nigeria, Romania, Sudan, and Zimbabwe. However, there is a positive relationship between economic growth and renewable energy consumption in Bhutan, Bulgaria, Algeria, Democratic Republic of the Congo, India, Iran, Kenya, Comoros, Mozambique, Central African Republic, Pakistan, Paraguay, Sri Lanka, Swaziland, Venezuela, and Zambia. The obtained results are consistent with the studies conducted by Apergis et al., (2010), Pao and Fu (2013), Sebri and Ben-Salha (2014), and Bhattacharya et al., (2016).

\section{CONCLUSION}


The effect of renewable energy consumption on economic growth was investigated in the present study. In this context, 49 non-OECD countries were analyzed for the period between 1980 and 2012. First, it is necessary to check the stationarity of the series. While the unit root test to be used needs to be a second generation unit root test, the use of a first generation unit root test could cause serious problems in the stationarity results of the series. For this reason, it is necessary to test the cross-section dependence among the series. Cross-section dependence was analyzed using Breusch-Pagan (1980) CDLM $_{1}$ test, Pesaran et al. (2004) $\mathrm{CDLM}_{2}$ test, and Pesaran et al. (2008) Bias Adjusted CD test. The results indicated that there was cross-section dependence both among the variables and across the panel. Thus, the unit root test and the cointegration test to be used would be second generation tests. Pesaran CADF (2007), which is a second generation unit root test, was used to examine the stationarity of the series. It was found that the series had a unit root at the level, and became stationary after their first differences were taken.

Once the series became stationary at the first difference I(1), the cointegration test was implemented. The long term relationship among the variables was analyzed by means of Westerlund (2008) Durbin-H cointegration test, which is a second generation cointegration test. Based on the findings, it was concluded that the series would move together in the long term.

After the detection of cointegration, the long term cointegration coefficients were estimated using the Common Correlated Effects (CCE). The results indicated a positive relationship between economic growth and renewable energy consumption in Bhutan, Bulgaria, Algeria, Democratic Republic of the Congo, India, Iran, Kenya, Comoros, Mozambique, Central African Republic, Pakistan, Paraguay, Sri Lanka, Swaziland, Venezuela, and Zambia. It was determined that renewable energy consumption was elastic in the Democratic Republic of the Congo since the elasticity coefficient of renewable energy consumption was found to be greater than 1 , but it was inelastic in the other countries based on the elasticity found between 0 and 1.

\section{REFERENCES}

Allen, R. C. (2009). The British industrial revolution in global perspective (pp. 135-181). Cambridge: Cambridge University Press.

Alper, F. Ö., \& Alper, A. E. (2017). Karbondioksit Emisyonu, Ekonomik Büyüme, Enerji Tüketimi Iliskisi: Türkiye Için Bir ARDL Sinir Testi Yaklasimi. Sosyoekonomi, 25(33), 145-156.

Apergis, N., \& Payne, J. E. (2010). Renewable energy consumption and economic growth: evidence from a panel of OECD countries. Energy policy, 38(1), 656-660.

Apergis, N., \& Payne, J. E. (2012). The electricity consumption-growth nexus: renewable versus non-renewable electricity in Central America. Energy Sources, Part B: Economics, Planning, and Policy, 7(4), 423-431.

Bhattacharya, M., Paramati, S. R., Ozturk, I., \& Bhattacharya, S. (2016). The effect of renewable energy consumption on economic growth: Evidence from top 38 countries. Applied Energy, 162, 733-741.

Breusch, T. S., \& Pagan, A. R. (1980). The Lagrange multiplier test and its applications to model specification in econometrics. The Review of Economic Studies, 239-253.

Fanchi, J. R., \&Fanchi, C. J. (2005). Energy in the 21st Century. Hackensack, NJ: World scientific.

Hall, C., Tharakan, P., Hallock, J., Cleveland, C., \& Jefferson, M. (2003). Hydrocarbons and the evolution of human culture. Nature, 426(6964), 318-322.

Herzer, D. (2016). Unions and Income Inequality: A Heterogeneous Panel Co- integration and Causality Analysis. Labour, 30(3), 318-346.

Im, K. S.,Pesaran, M. H., \&Shin, Y. (2003). Testing for unitroots in heterogeneous panels. Journal of econometrics, 115(1), 53-74.

Inglesi-Lotz, R. (2016). The impact of renewable energy consumption to economic growth: A panel data application. Energy Economics, 53, 58-63.

Johnson, G. L. (2006). Wind energy systems. Manhattan: Prentice-Hall. 


\section{Tuncer Gövdeli \& Tuba Başkonuş Direkçi}

Kraft, J. \&Kraft A. (1978) On the Relationship between Energy and GNP, Journal Energy Development, 3, 401403.

Menegaki, A. N. (2011). Growth and renewable energy in Europe: A random effect model with evidence for neutrality hypothesis. Energy Economics, 33(2), 257-263.

Michaelides, E. E. S. (2012). Alternative energy sources. Springer Science \& Business Media.

Omri, A., \& Chaibi, A. (2014). Nuclear energy, renewable energy, and economic growth in developed and developing countries: a modelling analysis from simultaneous-equation models. Renew Sustain Energy Rev, 42, 1012-1022.

Pao, H. T., \& Fu, H. C. (2013). Renewable energy, non-renewable energy and economic growth in Brazil. Renewable and Sustainable Energy Reviews, 25, 381-392.

Pesaran, M. H., (2004). General Diagnostic Tests for Cross Section Dependence in Panels. Cambridge Working Papers in Economics no. 435. University of Cambridge.

Pesaran, M. H. (2007). A simple panel unitroot test in the presence of cross-sectiondependence. Journal of AppliedEconometrics, 22(2), 265-312.

Pesaran, M. H., Ullah, A., \& Yamagata, T. (2008). A bias-adjusted LM test of error cross-section independence. The Econometrics Journal, 11(1), 105-127.

Sebri, M., \& Ben-Salha, O. (2014). On the causal dynamics between economic growth, renewable energy consumption, CO 2 emissions and trade openness: fresh evidence from BRICS countries. Renewable and Sustainable Energy Reviews, 39, 14-23.

Solow, R. M. (1956). A contribution to the theory of economic growth. The quarterly journal of economics, 6594.

Tiwari, A. K. (2011). Comparative performance of renewable and nonrenewable energy source on economic growth and $\mathrm{CO} 2$ emissions of Europe and Eurasian countries: A PVAR approach. Economics Bulletin, 31(3), 2356-2372.

Ucan, O., Aricioglu, E., \& Yucel, F. (2014). Energy consumption and economic growth nexus: evidence from developed countries in Europe. International Journal of Energy Economics and Policy, 4(3), 411.

Westerlund, J. (2008). Panel cointegration tests of the Fisher effect. Journal of Applied Econometrics, 23(2):193233.

Wrigley, E. A. (1990). Continuity, chance and change: The character of the industrial revolution in England. Cambridge University Press. 